\title{
The Influence of Experiential Marketing, Service Quality on Customer Loyalty and Satisfaction at the Pizza Hut Restaurant in the Tunjungan Plaza Surabaya
}

\author{
Ronald Setiobowo \\ University of Balikpapan, Indonesia \\ Ronald.setiobowo@uniba-bpn.ac.id
}

\begin{abstract}
This research aims is to understand and to analyze how experiential marketing, service quality influence to customers loyalty satisfaction at the The Pizza Hut Restaurant in the The Tunjungan Plaza Surabaya. Previous studies show there is a positive influence between the experiential marketing to service and customer satisfaction. As experiencing from evident that customers constantly come to the The Pizza Hut Restaurant every day, especially on the day of the weekend. Other factors may be affecting to customers who enjoy the service in this restaurant, such as restaurant environment, facilities, and life style. However, it does not clear how frequency will show the level of customer satisfaction. This research uses quantitative approach and uses a questionnaire to collect data. There are $\mathbf{1 5 0}$ questionnaires returned, the results obtained by researchers in obtaining the most is a civil servant class of income above 3 million-5 million and staying in Surabaya and aged 17-25 years followed by male gender.

Results show that the quality of the Pizza Hut service is good enough and marketing has effect to customers. As a result, customers come to the restaurant frequently. It can be seen that there is a positive effect between experiencing of service and loyalty customer.
\end{abstract}

Keywords - experiential marketing, service quality, customer loyalty, satisfaction

\section{INTRODUCTION}

The development of culinary business today can be said very rapidly. Many fast food restaurants offer a variety of food with their own characteristics so culinary enthusiasts are interested to try it. In order for customers to be loyal usually restaurants are also equipped with a comfortable sushi loyal restaurant is usually also equipped with comfortable environment, such as comfortable room, music and wi-fi service smoothly. The concept of experiential marketing states that in order to approach, gain and retain loyal customers, producers through their products need to bring unique, positive and memorable experiences to consumers [6]. In the culinary business a positive experience must be supported with good service quality, so that customers are satisfied and loyal.

Therefore the role of experiential marketing, service quality, satisfaction and loyalty need to be considered, in order to be able to maintain its position in the current competition.

According to [3] experiential marketing is one of the usual marketing activities undertaken by business people to attract consumers through their emotional side. The era of increasingly fierce business competition companies need to see opportunities by presenting uniqueness that differentiates with competitors. Reference [3] mentions that experiential marketing is a business that is used by companies or marketers to package the product so as to offer an emotional experience to touch the hearts and feelings of consumers

Customer loyalty (loyalty is the result of a consumer's satisfaction due to using a product or service from a company.Usually consumer loyalty occurs if the consumer is satisfied with the product or service so that the consumer has an emotional bond with the company Another aspect of loyalty is where the consumer is ready to recommend the company to friends, family members and colleagues-it is this emotional bond that makes consumers loyal and driven to continue doing business with companies and make recommendations [2].

Reference [2] suggests there are various things that can be categorized as consumer loyalty, such as repeat purchase, recommend products, ignoring a competitor's product. Reference [2] also said that 
satisfied consumers will more tell a positive experience to others and recommend the company. This is because experiential marketing seeks to create a positive experience for consumers after consuming products or services that can be used as a reference for marketers to predict consumer behavior in the future in the form of repeat purchase. As a result, the quality of good service will impact on the satisfaction in the future. Then, consumer satisfaction and consumer loyalty are integral aspects. Consumers will feel loyal to a product or service when consumers already feel the satisfaction of a product and service [4].

\section{METHODS}

This is a quantitative research approach and a causal research by using hypothesis. Causal research is useful for measuring relationships between research variables in experiential marketing, service quality, customer loyalty and customer satisfaction are useful for analyzing how a variable affects other variables [2].

\section{A. Identify Variables and Variable Measurement}

There are three kinds of variables: exogenous variable, intervening variable and endogenous variable. Exogenous variables are experiental marketing (EM) and service quality (SQ). Whereas, intervening variable is customer satifaction (CS), and endogenous variable is customer loyalty (CL).

Likert scale is a method that measures attitudes by expressing agreement or disapproval to certain subject, object or event. Method of measurement of variables used in this research is Likert Scale 5 points in the questionnaire.

The type of data used in this study is quantitative data, ie data in the form of numbers indicate responses or assessments of respondents. Sources of data in this study is primary data obtained directly from the object of research that is at the The Pizza Hut Restaurant in Surabaya who was elected to respondents in this study

The tool used to collect data in this study is a questionnaire. While the method of data collection is survey, that is by distributing questionnaires directly to consumers who visited The Pizza Hut Restaurant tunjungan plaza in Surabaya. The number of samples in this study amounted to 150 samples.

To process the data obtained then the use of analytical techniques Structural Equation Modeling (SEM) using LISREL 8.70 program for model formation and hypothesis testing. SEM is a collection of statistical techniques that can be used to analyze research problems that have a relatively complex set of relationships with statistical testing simultaneously.

\section{RESULTS}

Characteristics of 150 respondents can be explained from the sex, domicile, age, employment and income (allowance) per month.

Table I shows the number of female respondents $(51.3 \%)$ more dominant than the male respondents $(48.7 \%)$

TABLE I

CHARACTERISTICS of RESPONDENTS BASED on GENDER

\begin{tabular}{|l|l|l|}
\hline Gender & Frequency & Percentage(\%) \\
\hline Men & 73 & 48.7 \\
\hline Women & 77 & 51.3 \\
\hline Total & $\mathbf{5 0}$ & $\mathbf{1 0 0}$ \\
\hline
\end{tabular}

Table II shows respondents who are domiciled in Surabaya (59.3\%) and outside of Surabaya (40.7\%). The assessment on location is important to understand factors that influence customers to visit the place and what is motivation on it.

TABLE II

CHARACTERISTICS of RESPONDENTS by DOMICILED

\begin{tabular}{|l|l|l|}
\hline Domain & Frequency & Percentage (\%) \\
\hline Surabaya & 89 & 59.3 \\
\hline Outside Surabaya & 61 & 40.7 \\
\hline Total & $\mathbf{1 5 0}$ & $\mathbf{1 0 0}$ \\
\hline
\end{tabular}


TABLE III

CHARACTERISTICS of RESPONDENTS by AGE

\begin{tabular}{|l|l|l|}
\hline Age & Frequency & Percentage (\%) \\
\hline $17-25$ & 79 & 52.7 \\
\hline $26-35$ & 48 & 32.0 \\
\hline $36-45$ & 13 & 8.7 \\
\hline $46-55$ & 6 & 4.0 \\
\hline$\geq 56 \quad$ & 2.7 \\
\hline \multicolumn{1}{|c|}{ Total } & $\mathbf{1 5 0}$ & \\
\hline
\end{tabular}

Table III shows the number of dominant respondents aged $17-25$ years $(52.7 \%)$. This is because the majority of consumers of the Pizza Hut in The Tunjungan Plaza Surabaya are young people with high consumption of food and tend to like western-style food such as pizza. Table IV show that respondents in this study who work as a student is the largest $(58.0 \%)$ respondents and respondents who work public servants are the fewest respondents in this study at $11.3 \%$

TABLE IV

CHARACTERISTICS of RESPONDENTS BASED on PROFESSION

\begin{tabular}{|l|l|l|}
\hline \multicolumn{1}{|c|}{ Profession } & \multicolumn{1}{c|}{ Frequency } & \multicolumn{1}{c|}{ Percentage (\%) } \\
\hline Student & 87 & 58.0 \\
\hline Employees & 25 & 16.7 \\
\hline Servant & 17 & 11.3 \\
\hline Entrepreneur & 21 & 14.0 \\
\hline Total & $\mathbf{1 5 0}$ & $\mathbf{1 0 0}$ \\
\hline
\end{tabular}

Table V shows that the characteristics of respondents who have the highest income is $\mathrm{Rp}$ $1,000,000-\operatorname{Rp~} 3,000,000(56.7 \%)$ this is related to the dominant profession of respondents in this study are students, where most of the income (allowance) from parents

TABLE V

\begin{tabular}{|c|c|c|}
\hline Percent & Frequency & Revenue (\%) \\
\hline Rp 1,000,000-Rp 3,000,000 & 85 & 56.7 \\
\hline Rp 3,000,000-Rp 5,000,000 & 42 & 28.0 \\
\hline$\geq$ Rp 5,000,000 & 23 & 15.3 \\
\hline Total & $\mathbf{1 5 0}$ & $\mathbf{1 0 0}$ \\
\hline
\end{tabular}

Experiential marketing (X1) has a positive effect on customer satisfaction (Y1). Thus support the hypothesis 1. It explains that increased experiential marketing will make consumers become satisfied. This means that pizza pie restaurant in the Tunjungan Plaza Surabaya is able to fulfil the wishes and expectations of consumers

Service quality (X2) has a positive effect on customer satisfaction (Y1). Hence, this is supporting hypothesis 2 . This means that the performance of pizza pie restaurant in the Tunjungan Plaza Surabaya serving food and drinks on time. The quality of services provided also meets the expectations of consumers, therefore, consumers are satisfied

Customer satisfaction (Y1) has a positive impact on customer loyalty (Y2). Thus, this is supports the hypothesis 3. This is because satisfied consumers will lead to loyalty. Consumers are satisfied that the Pizza Hut Restaurant in the Tunjungan Plaza Surabaya is able to meet their expectations so that consumers will do re-buying or repurchase later on. This can be based on two factors: positive experience in perceived consumers and the performance of employees who are able to meet the expectations and desires of consumers which means, if satisfaction has increased the loyalty of consumers

Experiential marketing (X1) has a positive effect on customer loyalty (Y2). This supports hypothesis 4. It means the positive experience felt by consumers is able to make consumers become loyal to the Pizza Hut Restaurant in the Tunjungan Plaza Surabaya. Loyal attitudes in the show the consumer is to make a re-purchase and recommend the restaurant to friends and even relatives.

Service quality (X2) has no effect on customer loyalty (Y2). This is based on the quality of service that employees provide to consumers not entirely persistent consistently, meaning that consumers feel the service provided by employees can change at any time. This makes consumers feel disappointed towards employees who make consumers becoming disloyal.

Experiential marketing (X1) does not affect customer loyalty (Y2) through customer satisfaction (Y2). This is because consumers in fact just feel curious or just dabble the existing products in The Pizza Hut Restaurant in the Tunjungan Plaza Surabaya. Minimal experience of a product cannot 
lead to loyalty due to the absence of a definite satisfaction in measuring the most favourable menu from the consumers after consuming products that disappointed to employees who make consumers becoming disloyal

Relationship between service quality (X2) to customer loyalty (Y2) through customer satisfaction (Y1) has a positive effect. This supports the hypothesis 7 that consumers who are happy with the performance of employees will feel satisfied and lead to customers' loyalty. This means service quality can improve customer loyalty, only if satisfaction can be experienced by consumers directly.

\section{DISCUSSION}

Variable experiential marketing has a positive influence on customer satisfaction. This is because the The Pizza Hut Restaurant in the Tunjungan Plaza Surabaya able to meet the wishes and expectations of consumers. Experiential marketing has a major influence that the offer of new products in the restaurant offer able to make consumers want to try it. This shows that experiential marketing is not only offers features and benefits of a product but it is also to win the hearts of consumers.

Variable service quality has a positive influence on customer satisfaction. This is because the performance of The Pizza Hut Restaurant in the Tunjungan Plaza Surabaya serves food and drinks on time in service according to the results of this research.

Variable customer satisfaction has a positive effect on customer loyalty. This is because consumers who feel satisfied later will lead to loyalty [1]. Consumers are satisfied because pizza pie restaurant in the Tunjungan Plaza Surabaya able to meet their expectations so that consumers will do rebuying or repurchase later in accordance with the results of this research.

Variable experiential marketing has a positive influence on customer loyalty, this is because the consumer positive experience is felt by consumers able to make consumers loyal to the Pizza Hut Restaurant in the Tunjungan Plaza Surabaya. Loyal attitudes in the consumer show is by repurchase and recommend restaurant friendship and even relatives according to previous research results

Variable quality of service does not influence to Customer loyalty (consumer quality). This is based on the quality of service that employees provide to consumers does not completely survive consistently, meaning that the service provided by employees can change at any time. Employees who initially respond quickly become less responsive when the situation in a busy restaurant according to [5] where the causal relationship of the quality of service does not significantly affect consumer loyalty

\section{CONCLUSIONS}

Even though level of customers who come to the restaurant frequently cannot reflect to customers loyalty, however, this study shows interesting results, such as customers satisfaction on employee service is one of reason they will come frequently beside environment of restaurant as a factor that supporting this research. This is because there is a positive effect between experiencing of service and loyalty customer.

There are some limitations in this research that future researchers need to consider to look at wider such as the object of research, the number of respondent, and the aspects of research as well.

\section{REFERENCES}

[1] Aryani, D and Rosinta, F, 2010, The Effect of Service Quality on Customer Satisfaction in Shaping Loyalitas Pelanggan, Jurnal ilmu administrasi dan organisasi, Vol17, no2, Mei- Agus, 114-126

[2] Barnes,J G. (2003). Secrets of Customer Relationship Management[Rahasia Manajemen Hubungan Pelanggan]. Yogyakarta: Andi. ISBN 979-5363-921-4

[3] Christian, A. \& D, Dhamaryanti. (2013). Pengaruh Experiential Marketing terhadap Customer Satisfaction dan Customer Loyalty The Light Cup di surabaya Town Square, Jurnal manajemen Pemasaran Petra,.1 (2):1-13.

[4] Durianto, D. Sugiarto. \& Sitinjak, T. (2001). Strategi Menaklukkan Pasar. Jakarta. PT Gramedia Pustaka Utama

[5] Indriani, F. (2006). Experiential Marketing sebagai Suatu Strategi Dalam Menciptakan Customer Satisfaction dan Repeat Buying Untuk Meningkatkan Kinerja Pemasaran, Jurnal Studi Manajemen dan Organisasi, 3 (1), 28-39. 